\title{
Articles
}

\section{Synthesis and Characterization of Cobalt(II)/(III), Nickel(II) and Copper(II) Complexes of New 14, 15 and 16-Membered Macrocyclic Ligands}

\author{
Abdou Saad El-Tabl \\ Department of Chemistry Factlty of Science, Henoufia Lniwersity, Shebin El-Kom, Egypt \\ Received October 31, 2003
}

\begin{abstract}
A new series of nickel(II). cobalt(II)/(III) and copper(II) complexes of 14,15 and 16-membered of macrocyclic ligands have been prepared and characterized by elemental analy'ses. IR. UV-VIS and ${ }^{1} \mathrm{H}-\mathrm{NMR}$ spectra. magnetic susceptibilities. conductivities. DTA and ESR measurements. Molar conductances in DMF solution indicate that. the complexes are nonelectrolytes except (9-12) complexes. The electronic spectra show that. all complexes are square planar or distorted octahedral geometry. The ESR spectra of solid complexes (4). (8) and (11) show square planar of axial type symmetry $\left(\mathrm{d}_{\mathrm{*} 3 \mathrm{y} z}\right)$ with considerable covalent bond character. However. complex (12) shows a spectnum of octahedral geometry with $\mathrm{d}_{\mathrm{z} \text { 2 }}$ ground state. Complex (12) shows exploitation in reducing the amount of electron adducts formed in DNA during irradiation with low radiation products.
\end{abstract}

Key Words : Complexes, Syntheses. Spectral studies. Conductivity, Magnetism

\section{Introduction}

There has been considerable interest in the synthesis of transition metal complexes of macrocyclic ligand systems because they play vital roles in biological systems. ${ }^{1}$ Also, interest in these species stems largely from the enhanced kinetic and thermodynanic stability of their complexes relative to those of related open chain ligands. Generally macrocyclic complexes are also of interest because of the synthetic flexibility involved in their preparation which allows for systematic variation in parameters such as ring size. the nature of the donor atoms. and the steric and electronic effects associated with the groups located on the periphery of the macrocyclic ring. ${ }^{2}$ Increasing interest in the macrocyclic metal complexes as model compounds for active sites in enzymes comprising corrin or porphyrin moieties has resulted in various preparative routes to such compounds. Earlier work had demonstrated that use of a difunctional macrocycle in such reactions resulted in the production of polymers that were highly cross-linked and hence insoluble. ${ }^{3}$ The aim of this work was the production of symunetric and asymmetric macrocyclic complexes containing a single reactive functional site. New cobalt(II)/(III), nickel(II) and copper(II) have been prepared and characterized and also. to study the effect of $\gamma$ radiation on DNA molecules in the presence of cobalt(III) complex (12).

\section{Experimental Section}

All chemicals and solvents were reagent grade and used as received. $\mathrm{C} . \mathrm{H}, \mathrm{N}$ and $\mathrm{M}$ analyses were determined at the

\footnotetext{
Corresponding Author. e-mail: asaeltablitayahoo.com
}

Analytical Unit of Cairo University. Egypt. The complexes were dried in air or in vacuo over $\mathrm{P}_{2} \mathrm{O}_{5}$. IR spectra (as $\mathrm{KBr}$ pellets) and (as Nujol mull between $\mathrm{CsBr}$ prisms) were recorded on a Perkin-Elmer 681 spectrophotometer. Electronic spectra in the $200-900 \mathrm{~nm}$ region were recorded on a Perkin-Elmer 550 spectrophotometer. ${ }^{1} \mathrm{H}$-NMR spectra were obtained with a Perkin-Elmer R32-90 MHz spectrometer using TMS as internal standard. Magnetic susceptibilities were measured at $25^{\circ} \mathrm{C}$ by the Gouy method using mercuric tetrathiocyanato-cobaltate(II) as the magnetic standard. Diamagnetic corrections were estimated from Pascal's constant. The magnetic susceptibilities were calculated from the equation $\mu_{\text {eff }}=2.84 \sqrt{\chi_{\mathrm{M}^{\text {cin }}} \cdot \mathrm{T}}$. Molar conductances were measured on a Tacussel type $\mathrm{CD}_{\mathrm{N}} \mathrm{NG}$ conductivity bridge using $10^{-3} \mathrm{M}$ DMF. DTA analy sis was carried out in air (20$700{ }^{\circ} \mathrm{C}$ ) using a Schimadzu DT-30 thermal analyzer. The ESR spectra of solid complexes $(+.8$ and 11$)$ at room temperature and $(12)$ in the $\mathrm{CD}_{3} \mathrm{OD}+\mathrm{D}_{2} \mathrm{O}(10 \%)$ in the form of small beads at $77 \mathrm{~K}$ were measured using a Varian E-109 spectrometer. The complex (12) and DNA molecules were exposed to ${ }^{6 i j} \mathrm{Co}$-rays at $77 \mathrm{~K}$ using a $0.22 \mathrm{M} \mathrm{radh}^{-1}$ dose for $5 \mathrm{~h}$ (Leicester University. England). DPPH was used as the marker. The TLC of the all complexes confimed their purity.

Preparation of the ligands.

$\mathrm{H}_{2} \mathrm{~L}^{1}$, Compound (1). To a solution of 4-nitro-1.2diaminobenzene $(5.0 \mathrm{gm} .0 .033 \mathrm{~mol})$ in DMF $\left(100 \mathrm{~cm}^{3}\right)$ was added to 3-ethosyvinylidene-2.4-pentanedione $(5.1 \mathrm{gm}$. $0.033 \mathrm{~mol})$ in $\left(20 \mathrm{~cm}^{3}\right)$ DMF. A few drops of conc. $\mathrm{HCl}$ was added and the mixture was refluxed for $4 \mathrm{~h}$. then the solvent was reduced to a small volume in vacuo and methanol was added to precipitate the yellow product. The solid was collected by filtration. washed with methanol, and then dried 
over $\mathrm{P}_{4} \mathrm{O}_{4}$. The analytical data are given in Table 1 .

$\mathbf{H}_{2} \mathrm{~L}^{2}$, Compound (5). To a solution of 4-nitro-1.2diaminobenzene ( $2.5 \mathrm{gm} .0 .0165 \mathrm{~mol})$ in DMF $\left(50 \mathrm{~cm}^{3}\right)$ was added to 3-ethoxyvinylidene-2.4-pentanedione $(5.1 \mathrm{gm}$. $0.033 \mathrm{~mol})$ in $\left(30 \mathrm{~cm}^{3}\right)$ DMF. Using a method described above. the solid (I) was collected and then dried in air. To $\left(5.0 \mathrm{gm} .0 .013 \mathrm{~mol}\right.$ ) of a solid (I) in DMF $\left(50 \mathrm{~cm}^{3}\right)$ was added to 1.3 -diaminopropane $\left(1.1 \mathrm{~cm}^{3} .0 .013 \mathrm{~mol}\right)$ in the presence of a few drops of conc. $\mathrm{HCl}$. The reaction mixture was refluxed for $3 \mathrm{~h}$. then the solvent volume was reduced in vacto and methanol was added to precipitate the yellowish brown product which was collected by filtration. washed with methanol and then dried over $\mathrm{P}_{4} \mathrm{O}_{\text {uci. The analytical data }}$ are given in Table 1<smiles>CC(=O)C(=CNc1ccc(C#N)cc1NC=C(C(C)=O)C(C)=O)C(C)=O</smiles>

(I)
Preparation of metal complexes. Neutral dichloro- $\beta$ diketone and 3-(benzylidene)- $\beta$-diketone cobalt(II) complexes were prepared by literature procedure. ${ }^{4}$

Complexes (2-4) using $\mathrm{H}_{2} \mathrm{~L}^{1}$ : To a rapidly stirred suspension of $\mathrm{H}_{2} \mathrm{~L}^{3}(5.0 \mathrm{gm}, 0.01 \mathrm{~mol})$ in methanol $\left(70 \mathrm{~cm}^{3}\right)$ was added sodium hydroxide $(0.8 \mathrm{gm} .0 .02 \mathrm{~mol})$ in $\left(15 \mathrm{~cm}^{3}\right) \mathrm{H}_{2} \mathrm{O}$ followed by metal(II) acetate. $\left[\mathrm{Ni}(\mathrm{OAc})_{2} \cdot 4 \mathrm{H}_{2} \mathrm{O}\right.$. complex (2). $\mathrm{Co}(\mathrm{OAc})_{2}-4 \mathrm{H}_{2} \mathrm{O}$. complex $(3),(2.5 \mathrm{gm}, 0.01 \mathrm{~mol})$ and $\mathrm{Cu}(\mathrm{OAc})_{2} \mathrm{H}_{2} \mathrm{O}$, complex (4), (2.0 gm, $\left.\left.0.01 \mathrm{~mol}\right)\right]$. The reaction mixture was refluxed with stirring for $2 \mathrm{~h}$. A solid complex appeared was collected by filtration and then washed with warm methanol and dried. The analytical data are given in Table 1.

Complexes (6-8) using $\mathrm{H}_{2} \mathrm{~L}^{2}$ : To a rapidly stirred suspension of $\mathrm{H}_{2} \mathrm{~L}^{2}(5.0 \mathrm{gm}, 0.01 \mathrm{~mol})$ in methanol $\left(50 \mathrm{~cm}^{3}\right)$ was added sodium hydroxide $(0.89 \mathrm{gm}, 0.02 \mathrm{~mol})$ in $\left(15 \mathrm{~cm}^{3}\right)$. $\mathrm{H}_{2} \mathrm{O}$ followed by $\mathrm{Ni}(\mathrm{OAc})_{2} 4 \mathrm{H}_{2} \mathrm{O}$. complex (6). $\mathrm{Co}(\mathrm{OAc})_{2}$. $4 \mathrm{H}_{2} \mathrm{O}$. complex $(7),(2.5 \mathrm{gm}, 0.01 \mathrm{~mol})$ and $\mathrm{Cu}(\mathrm{OAc})_{2} \cdot \mathrm{H}_{2} \mathrm{O}$. complex (8). (2.2 gm. $0.01 \mathrm{~mol})]$. Using a method described above. the product was removed by filtration. washed with warm methanol and then dried. The analytical data are given in Table 1 .

Complexes (9): This complex (9) was prepared as follows:- A mixture of 3-(benzy lidene)- $\beta$-diketone cobalt(II). (Scheme 1) (5.0 gm. $0.016 \mathrm{~mol}$ ) and piperidine in DMF (100 $\left.\mathrm{cm}^{3}\right)$ was gradually added to a 1.3-diaminopropane $(1.2 \mathrm{gm}$. $0.016 \mathrm{~mol})$ in DMF $\left(25 \mathrm{~cm}^{3}\right)$ in a round botton flask. The mixture was refluxed for $3 \mathrm{~h}$. Upon concentration to one-

Table 1. Analytical, physical and themmal properties of the ligands and their metal complexes

\begin{tabular}{|c|c|c|c|c|c|c|c|c|c|c|}
\hline \multirow{2}{*}{ Comp. No.Fonnula } & \multirow{2}{*}{ Colour } & \multirow{2}{*}{$\begin{array}{l}\text { Yield } \\
(\%)\end{array}$} & \multirow{2}{*}{$\begin{array}{l}\text { M.p. } \\
\left(\mathrm{C}^{\circ}\right)\end{array}$} & \multirow{2}{*}{$\stackrel{\mu_{\mathrm{eff}}}{(\mathrm{B} . \mathrm{M})}$} & \multirow{2}{*}{$\begin{array}{c}\Lambda_{\mathrm{tu}} \\
\left(\Omega^{-1} \mathrm{~cm}^{2} \mathrm{mlol}^{-1}\right)\end{array}$} & \multicolumn{5}{|c|}{ Found (Calcd ) \% } \\
\hline & & & & & & $\mathrm{C}$ & $\mathrm{H}$ & $\mathrm{N}$ & $\mathrm{M}$ & $\mathrm{Cl}$ \\
\hline $\begin{array}{c}\text { (1) } \mathrm{H}_{2} \mathrm{~L}^{1} \\
{\left[\mathrm{C}_{2-4} \mathrm{H}_{2} \mathrm{~N}_{5} \mathrm{O}_{6}\right]}\end{array}$ & yellow & 85 & 168 & - & - & $\begin{array}{c}58.7 \\
(58.8)\end{array}$ & $\begin{array}{l}4.5 \\
(4.5)\end{array}$ & $\begin{array}{c}17.2 \\
(17.1)\end{array}$ & $\begin{array}{l}- \\
-\end{array}$ & $\begin{array}{l}- \\
-\end{array}$ \\
\hline$\stackrel{(2)}{\left[\mathrm{C}_{24} \mathrm{H}_{20} \mathrm{~N}_{6} \mathrm{O}_{5} \mathrm{Ni}\right] \cdot 2 \mathrm{H}_{2} \mathrm{O}}$ & red & 78 & 195 & diamag. & 13.2 & $\begin{array}{r}49.6 \\
(49.4)\end{array}$ & $\begin{array}{l}4.0 \\
(4.1)\end{array}$ & $\begin{array}{c}14.2 \\
(14.4)\end{array}$ & $\begin{array}{c}9.9 \\
(10.1)\end{array}$ & $\begin{array}{l}- \\
-\end{array}$ \\
\hline$\stackrel{(3)}{\left[\mathrm{C}_{24} \mathrm{H}_{20} \mathrm{~N}_{6} \mathrm{O}_{6} \mathrm{Co}\right] \cdot 2 \mathrm{H}_{2} \mathrm{O}}$ & brown & 82 & 200 & 4.91 & 10.8 & $\begin{array}{c}49.5 \\
(49.4)\end{array}$ & $\begin{array}{l}4.1 \\
(4.1)\end{array}$ & $\begin{array}{c}14.5 \\
(14.4)\end{array}$ & $\begin{array}{c}10.3 \\
(10.1)\end{array}$ & $\begin{array}{l}- \\
-\end{array}$ \\
\hline $\begin{array}{c}(\mathbf{4}) \\
{\left[\mathrm{C}_{2}+\mathrm{H}_{20} \mathrm{~N}_{6} \mathrm{O}_{5} \mathrm{Cul}\right] \cdot \mathrm{H}_{2} \mathrm{O}}\end{array}$ & brown & 75 & 195 & 1.95 & 11.8 & $\begin{array}{c}50.4 \\
(50.6)\end{array}$ & $\begin{array}{l}4.0 \\
(3.9)\end{array}$ & $\begin{array}{c}15.0 \\
(14.8)\end{array}$ & $\begin{array}{c}11.3 \\
(11.1)\end{array}$ & $\begin{array}{l}- \\
-\end{array}$ \\
\hline $\begin{array}{c}\text { (5) } \mathrm{H}_{2} \mathrm{~L}^{2} \\
{\left[\mathrm{C}_{21} \mathrm{H}_{25} \mathrm{~N}_{5} \mathrm{O}_{4}\right] \cdot 2 \mathrm{H}_{2} \mathrm{O}}\end{array}$ & $\begin{array}{l}\text { vellowish } \\
\text { brown }\end{array}$ & 83 & 165 & - & - & $\begin{array}{c}56.1 \\
(56.3)\end{array}$ & $\begin{array}{c}6.5 \\
(6.5)\end{array}$ & $\begin{array}{c}15.4 \\
(15.6)\end{array}$ & $\begin{array}{l}- \\
-\end{array}$ & $\begin{array}{l}- \\
-\end{array}$ \\
\hline$\frac{(6)}{\left[\mathrm{C}_{21} \mathrm{H}_{23} \mathrm{~N}_{5} \mathrm{O}_{4} \mathrm{Ni}\right] \cdot 2 \mathrm{H}_{2} \mathrm{O}}$ & red & 82 & 200 & diamag & 12.3 & $\begin{array}{c}50.1 \\
(50.0)\end{array}$ & $\begin{array}{c}5.4 \\
(5.4)\end{array}$ & $\begin{array}{l}14.0 \\
(13.9)\end{array}$ & $\begin{array}{l}11.8 \\
(11.6)\end{array}$ & $\begin{array}{l}- \\
-\end{array}$ \\
\hline $\begin{array}{c}(7) \\
{\left[\mathrm{C}_{21} \mathrm{H}_{3} \leqslant \mathrm{~N}_{\xi} \mathrm{O}_{4} \mathrm{Co}\right] \cdot 2 \mathrm{H}_{5} \mathrm{O}}\end{array}$ & deep brown & 76 & 205 & 4.75 & 13.1 & $\begin{array}{c}50.1 \\
(50.0)\end{array}$ & $\begin{array}{c}5.4 \\
(5.4)\end{array}$ & $\begin{array}{l}14.0 \\
(13.9)\end{array}$ & $\begin{array}{c}11.8 \\
(11.7)\end{array}$ & $\begin{array}{l}- \\
-\end{array}$ \\
\hline$\left[\begin{array}{l}(8) \\
{\left[\mathrm{C}_{23} \mathrm{H}_{23} \mathrm{~N}_{3} \mathrm{O}_{4} \mathrm{Cu}\right] \cdot 2 \mathrm{H}_{2} \mathrm{O}}\end{array}\right.$ & brown & 80 & 198 & 1.87 & 13.8 & $\begin{array}{c}49.6 \\
(49.5)\end{array}$ & $\begin{array}{c}5.3 \\
(5.3)\end{array}$ & $\begin{array}{c}13.8 \\
(13.7)\end{array}$ & $\begin{array}{l}12.5 \\
(12.4)\end{array}$ & $\begin{array}{l}- \\
-\end{array}$ \\
\hline$\frac{(9)}{\left[\mathrm{C}_{3 / 3} \mathrm{H}_{3 \mathrm{r}} \mathrm{N}_{4} \mathrm{Co}\right] \mathrm{Cl}_{2} \cdot \mathrm{H}_{2} \mathrm{O}}$ & $\begin{array}{l}\text { dull } \\
\text { red }\end{array}$ & 75 & 212 & 4.8 & 115 & $\begin{array}{c}60,0 \\
(60.2)\end{array}$ & $\begin{array}{c}6.1 \\
(6.3)\end{array}$ & $\begin{array}{c}9.1 \\
(9.3)\end{array}$ & $\begin{array}{c}9.0 \\
(8.8)\end{array}$ & $\begin{array}{c}12.0 \\
(11.8)\end{array}$ \\
\hline$\stackrel{(\mathbf{1 0})}{\left[\mathrm{C}_{300} \mathrm{H}_{3} \mathrm{~N}_{4} \mathrm{Ni}\right] \mathrm{Cl}_{2} \cdot 2 \mathrm{H}_{2} \mathrm{O}}$ & red & 78 & 208 & diamag & 118 & $\begin{array}{c}58.4 \\
(58.5)\end{array}$ & $\begin{array}{c}6.3 \\
(6.4)\end{array}$ & $\begin{array}{c}9.1 \\
(9.0)\end{array}$ & $\begin{array}{c}9.7 \\
(9.5)\end{array}$ & $\begin{array}{l}11.2 \\
(11.4)\end{array}$ \\
\hline$\frac{(11)}{\left[\mathrm{C}_{3 \mid} \mathrm{H}_{3}, \mathrm{~N}_{4} \mathrm{Cu}\right] \mathrm{Cl}_{2} \cdot 2 \mathrm{H}_{2} \mathrm{O}}$ & violet & 75 & 210 & 2.0 & 123 & $\begin{array}{c}57.9 \\
(58.1)\end{array}$ & $\begin{array}{c}6.2 \\
(6.4)\end{array}$ & $\begin{array}{r}8.7 \\
(8.9)\end{array}$ & $\begin{array}{c}9.9 \\
(10.1)\end{array}$ & $\begin{array}{l}11.5 \\
(11.4)\end{array}$ \\
\hline$\stackrel{(12)}{\left[\mathrm{C}_{1}: \mathrm{H}_{3} \mathrm{~N} \mathrm{~N}_{3} \mathrm{O}_{4} \mathrm{CO}\right] \mathrm{Cl}_{3} \cdot \mathrm{H}_{2} \mathrm{O}}$ & Orange & 81 & 192 & diamag & 168 & $\begin{array}{c}34.0 \\
(34.2)\end{array}$ & $\begin{array}{l}6.5 \\
(6.3)\end{array}$ & $\begin{array}{l}18.2 \\
(18.6)\end{array}$ & $\begin{array}{c}9.6 \\
(9.8)\end{array}$ & $\begin{array}{l}180 \\
(17.8)\end{array}$ \\
\hline
\end{tabular}



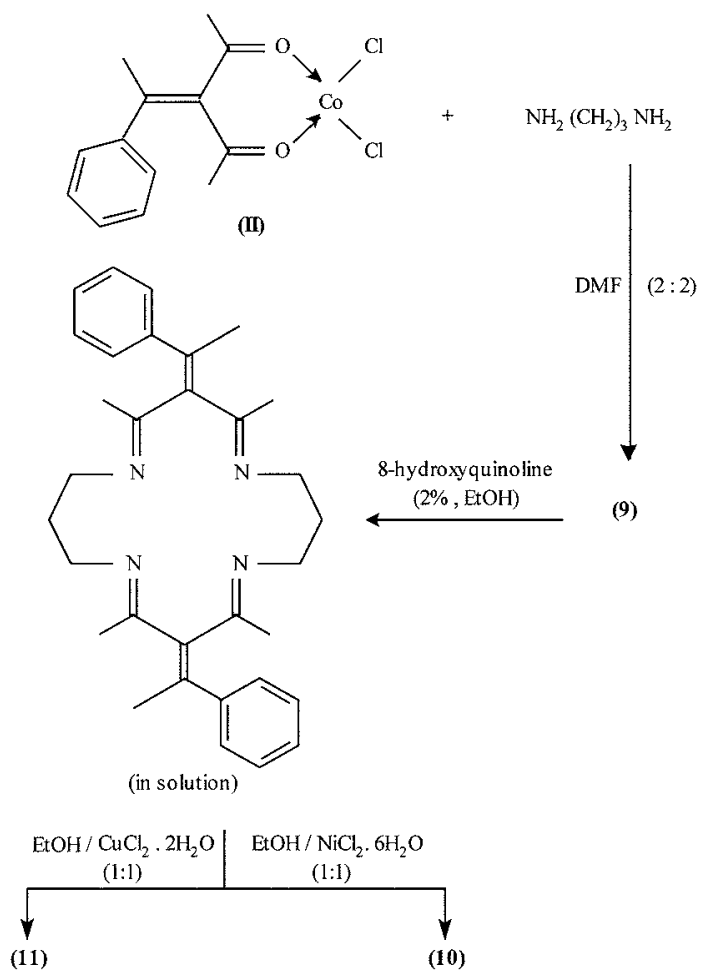

Scheme 1

third volume followed by the addition of petroleum ether ( 3 volume) and subsequent cooling at $0{ }^{\circ} \mathrm{C}(2 \mathrm{~h})$. Dull red crystalline solid product precipitated. This product was removed by filtration, washed with $50 \%$ (v/v) $\mathrm{MeOH}-$ $\mathrm{Me}_{2} \mathrm{CO}$ and dried. The analytical data are given in Table 1.

Complexes (10) and (11): Complexes (10) and (11) were prepared as follows:- In a two-necked $250 \mathrm{~cm}^{3}$ roundbottomed flask equipped with a condenser and a stirrer. Complex (9) (5.0 gm. 0.008 mol) was dissolved in DMF (50 $\left.\mathrm{cm}^{3}\right)$. An aqueous solution of $\mathrm{NaOH}(0.66 \mathrm{gm}, 0.016 \mathrm{~mol})$ was added for neutralization. 8-hydroxyquinoline $(\mathrm{EtOH}$ solution. $2 \%$ ) was added. then the mixture was heated to 60 $80{ }^{\circ} \mathrm{C}$ until the light brown amorphous cobalt oxinate became crystalline. The latter was allowed to settle at room temperature and was removed by filtration. The filtrate was concentrated and $\mathrm{NiCl}_{2} \cdot 6 \mathrm{H}_{3} \mathrm{O}(7.5 \mathrm{gm} .0 .016 \mathrm{~mol})(\mathbf{1 0})$ or $\mathrm{CuCl}_{2} 2 \mathrm{H}_{2} \mathrm{O}(2.8 \mathrm{gm}, 0.016 \mathrm{~mol})$ in ethanol $\left(50 \mathrm{~cm}^{3}\right) .(11)$ was added. The formed complexes were filtred off. washed with warm $\mathrm{E} t \mathrm{OH}$ and dried. The analytical data are given in Table 1.

Complex (12): Complex (12) was prepared as a method used for preparaing $\left[\mathrm{Co}\left(\mathrm{NO}_{2}\right)_{2}\right.$-sar $\left.)\right] \mathrm{Cl}_{3}{ }^{5}$

\section{Results and Discussion}

The reaction of 3-ethoxy vinylidene-2.4-pentanedione with 4-nitro-1.2-diaminobenzene $(2: 2)$ or $(2: 1)$ in DMF. via a Michael addition followed by elimination. give the $2: 2$ substitution product $\mathrm{H}_{2} \mathrm{~L}^{l}(\mathbf{1})$ and (2:1) product (I) which is reacted directly with 1.3-diaminopropane to give $\mathrm{H}_{2} \mathrm{~L}^{2}(\mathbf{5})$<smiles>CC(=O)C(=CNc1ccc([N+](=O)[O-])cc1N/C=C(/C(C)=O)C(C)=Nc1ccc([N+](=O)[O-])cc1N=C(C)C(C)=O)C(C)=O</smiles>

(1)<smiles></smiles>

$M=N i(I)$

$M=\operatorname{Co}(I I)$

$\mathrm{M}=\mathrm{Cu}(\mathrm{II})$

$$
\begin{aligned}
& \mathrm{n}=2 \\
& \mathrm{n}=2 \\
& \mathrm{n}=2
\end{aligned}
$$

(2)

(3)

(4)<smiles>CC(=O)C(=CNc1ccc([N+](=O)[O-])cc1N/C=C(/C(C)=O)C(C)=NCCCCN=C(C)C(C)=O)C(C)=O</smiles>

(5)

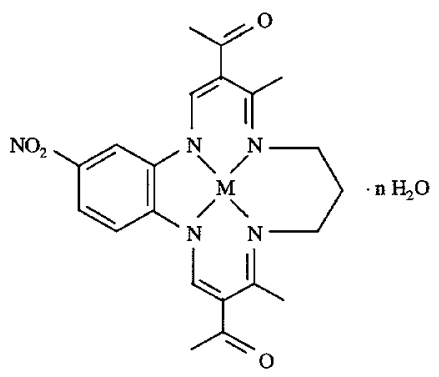

$\mathrm{M}=\mathrm{Ni}(\mathrm{II})$
$\mathrm{M}=\mathrm{Co}(\mathrm{II})$
$\mathrm{M}=\mathrm{Cu}(\mathrm{II})$ $\mathrm{n}=2$

$\mathrm{n}=2$

$\mathrm{n}=2$

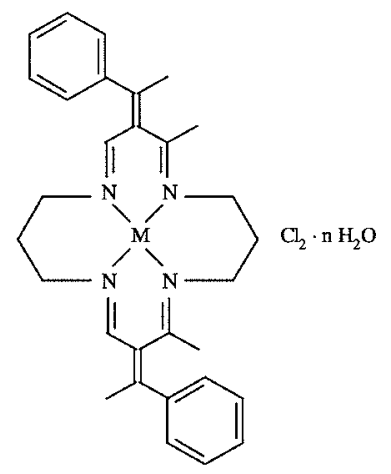

$\mathrm{M}=\mathrm{CO}(\mathrm{II})$
$\mathrm{M}=\mathrm{Ni}(\mathrm{II})$
$\mathrm{M}=\mathrm{Cu}(\mathrm{II})$

$\mathbf{a}=1$

(9)

$n=2$

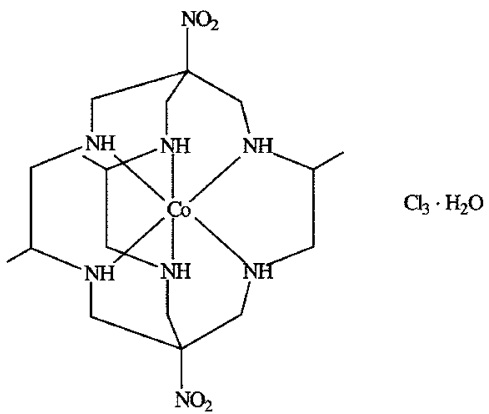

(12)

Figure 1 
Table 2. IR spectral $\left(\mathrm{cm}^{-1}\right)$ of the ligands and their metal complexes

\begin{tabular}{|c|c|c|c|c|c|c|}
\hline Comp. No. & $\mathrm{v}(\mathrm{N}-\mathrm{H} / \mathrm{O}-\mathrm{H})$ & $v(C=0)$ & $\mathrm{v}(\mathrm{C}=\mathrm{N})$ & $v(C=C)$ & $v\left(\mathrm{NO}_{2}\right)$ & $v(M-N)$ \\
\hline (1) & 3230,3150 & 1650 & 1612 & 1570,1595 & 1330,1525 & - \\
\hline (2) & $3630-3100$ & 1638 & 1605 & 1568,1590 & 1320,1523 & 570 \\
\hline (3) & $3640-3120$ & 1640 & 1608 & 1567,1592 & 1325,1530 & 565 \\
\hline (4) & $3600-3130$ & 1640 & 1605 & 1565,1590 & 1320,1515 & 570 \\
\hline (5) & $\begin{array}{l}3430,3350 \\
3560-3150\end{array}$ & 1650 & 1610 & 1580,1598 & 1320,1512 & - \\
\hline (6) & $3630-3050$ & 1640 & 1605 & 1575,1595 & 1317,1520 & 571 \\
\hline (7) & $3640-3120$ & 1640 & 1605 & 1571,1595 & 1316,1518 & 565 \\
\hline (8) & $3630-3130$ & 1638 & 1606 & 1578,1596 & 1315,1515 & 570 \\
\hline (9) & $3360-3100$ & - & 1608 & 1585,1618 & - & 550 \\
\hline (10) & $3420-3150$ & - & 1610 & 1582,1615 & - & 545 \\
\hline (11) & $3400-3120$ & - & 1607 & 1580,1616 & - & 560 \\
\hline (12) & $\begin{array}{l}3480-3395 \\
3350-3120\end{array}$ & - & - & - & 1350,1560 & 575 \\
\hline
\end{tabular}

\section{(Figure 1)}

A suspension of ligands (1) and (5) in methanol at reflux in the presence of sodium hydroxide reacts with metal(II) acetate to generate the corresponding complexes (Figure 1) in high yield (75-82\%). The same complexes were obtained using the template reaction. Complexes (9-11) were prepared according to Scheme 1 .

Analytical and physical data (Table 1), and spectral data (Tables 2 and 3 ) are compatible with the proposed structures (Figure 1). The complexes are coloured. stable in air and partialy soluble in common solvents except DMF and DMSO. The ${ }^{\mathrm{H}} \mathrm{H}-\mathrm{NMR}$ spectra of the compounds (1) and (5) exhibit signals in the $8.2-8.7 \mathrm{ppm}$ range corresponding to aromatic and methine protons and in the $2.4-2.6 \mathrm{ppm}$ range due to the four acetyl group protons. Resonances at 11.3$11.8 \mathrm{ppm}$ range were assigned to the $\mathrm{NH}$ group. This downfield phenomenon is attributed to hydrogen bonding. Compound (5) shows signals at $2.0-3.8 \mathrm{ppm}$ range. assigned to methylene groups. ${ }^{7}$ Complex (12) shows resonances at 2.72. 2.85 and $2.96 \mathrm{ppm}$, ascribed to the propylenediamine methylene protons. another two peaks appear at 3.41 and $3.55 \mathrm{ppm}$ corresponding to the methylene groups of the caps another peak at $2.48 \mathrm{ppm}$. assigned to the protons of methyl group of the propylenediamine. A single symmetrical resonance appears at $7.9 \mathrm{ppm}$ assigned to the $\mathrm{NH}$ group."

IR spectra. Important spectral bands for the ligands and their metal complexes are presented in Table 2 . The IR spectra of the ligands. (1) and (5) show two bands in the $3430-3150 \mathrm{~cm}^{-1}$ range assigned to $v(\mathrm{NH})$. Another band appears at $1650 \mathrm{~cm}^{-1}$ due to $v(\mathrm{C}=\mathrm{O})$ of acetyl group. The $\nu(\mathrm{C}=\mathrm{N})$ appears at 1612 and $1610 \mathrm{~cm}^{-1}$ respectively. ${ }^{9}$ Two bands appear in the $1598-1570 \mathrm{~cm}^{-1}$ range assigned to $v(\mathrm{C}=\mathrm{C})_{\mathrm{Al}}$ and $v(\mathrm{C}=\mathrm{C})_{\mathrm{Ar}}$ groups respectively and two bands at $1525-1320 \mathrm{~cm}^{-1}$ range ascribed to $v\left(\mathrm{NO}_{2}\right)$ group. The IR spectra of the complexes exhibit new bands and shifts of characteristic bands. The $v(\mathrm{C}=\mathrm{O})$ of acetyl group was observed at a lower frequency (1640 and $1638 \mathrm{~cm}^{-1}$ ). indicating minor change in symmetry of this group due to metal coordination. The absence of $v(\mathrm{NH})$ in the complexes (2-4. 6-8) indicates the aza proton is lost upon metal ion complexion. However. complex (12) shows a broad band in the $3480-3395 \mathrm{~cm}^{-1}$ range. assignable to the $\mathrm{NH}$ group. In each spectrum of metal complexes a medium intensity band is observed at $575-545 \mathrm{~cm}^{-1}$ range, assigned to the metalnitrogen stretching vibration. ${ }^{10}$ Bands at $3640-3100 \mathrm{~cm}^{-1}$ range due to $v(\mathrm{OH})$ of water molecules associated with the compounds. ${ }^{11.12}$ The $v(\mathrm{C}=\mathrm{N})$ is shifted towards a lower wave number by $4-7 \mathrm{~cm}^{-1}$ range $(2-4,6-8)$ indicating a decrease in the $\mathrm{C}=\mathrm{N}$ bond order as a result of $\mathrm{M}-\mathrm{N}$ bond formation, ${ }^{10}$ however. complexes $(9-11)$ show $v(\mathrm{C}=\mathrm{N})$ band at $1610-1608 \mathrm{~cm}^{-1}$ range. The bands at $1585-1565$ and $1618-1590 \mathrm{~cm}^{-1}$ ranges assigned to $v(\mathrm{C}=\mathrm{C})_{\mathrm{Al}}$ and $v(\mathrm{C}=\mathrm{C})_{\mathrm{Ar}}$ respectively. The complexes (2-4, 6-8 and 12) show two bands at $1350-1315$ and $1560-1512 \mathrm{~cm}^{-1}$ ranges. assigned to $v\left(\mathrm{NO}_{2}\right)$ group. Catalytic reduction of a suspension complex (2) in ethỵl acetate solution by hydrogen readily produced the corresponding primary amine substituted macrocycle. This complex was confirmed by microanaly ses data and IR spectrum which gives a characteristic bands at 3320 and $3250 \mathrm{~cm}^{-1}$, assigned to $v\left(\mathrm{NH}_{2}\right)$ group. ${ }^{7}$

Conductivity. The molar conductances of the complexes (Table 1). indicate their non-electrolytic nature except (9-12) which have high values suggesting $1: 2$ or $1: 3$ electrolytes. ${ }^{9.13 .14}$

Magnetic moment. The magnetic moments for the complexes are shown in Table 1. Complexes (2). (6). (10) and (12) are diamagnetic and the complexes (3). (7) and (9) show values $4.91,4.75$ and 4.8 B.M. respectively, indicating high spin, cobalt(II) complexes. ${ }^{10}$ However. the complexes (4). (8) and (11) show values 1.95, 1.87 and 2.0 B.M. respectively, indicating $\mathrm{Cu}$ (II) square planar complexes. 4.15 .16

Electronic spectra. The electronic spectra of the ligands and their complexes are summarized in Table 3 . The ligands (1) and (5) give bands at $298 \mathrm{~nm}\left(\varepsilon=0.45 \times 10^{-3} \mathrm{~mol}^{-1} \mathrm{~cm}^{2}\right)$. $290 \mathrm{~nm}\left(\varepsilon=1.8 \times 10^{-3} \mathrm{~mol}^{-1} \mathrm{~cm}^{-}\right)$and $310 \mathrm{~nm}(\varepsilon=0.75 \times$ $\left.10^{-3} \mathrm{~mol}^{-1} \mathrm{~cm}^{2}\right) .314 \mathrm{~nm}\left(\varepsilon=0.32 \times 10^{-3} \mathrm{~mol}^{-1} \mathrm{~cm}^{2}\right)$. These bands were assigned to $\pi-\pi^{*}$ transitions within the ligands 
Table 3. Electronic spectra of the ligands and their metal complexes

\begin{tabular}{ccc}
\hline $\begin{array}{c}\text { Comp. } \\
\text { No. }\end{array}$ & \multicolumn{1}{c}{$\begin{array}{c}\lambda \mathrm{max} \\
(\mathrm{mm})\end{array}$} & Medium \\
\hline (1) & $298 \mathrm{nnn}\left(\varepsilon=0,45 \times 10^{-3} \mathrm{~mol}^{-1} \mathrm{~cm}^{2}\right)$ & DMF \\
& $310 \mathrm{nnn}\left(\varepsilon=0,75 \times 10^{-3} \mathrm{~mol}^{-1} \mathrm{~cm}^{2}\right)$ & - \\
(2) & $540,490,350,280$ & N.M. \\
& $510,475,330,268$ & DMF \\
(3) & $535,465,348,300$ & N.M. \\
& $508,430,325,290$ & DMF \\
(4) & $546,505,350,277$ & N.M. \\
& $510,490,300,268$ & DMF \\
(5) & $2901 \mathrm{~mm}\left(1.8 \times 10^{-2} \mathrm{~mol}^{-1} \mathrm{~cm}^{2}\right)$ & DMF \\
& $3141 \mathrm{~nm}\left(0,32 \times 10^{-2} \mathrm{~mol}^{-1} \mathrm{~cm}^{2}\right)$ & - \\
(6) & $540,438,350,306$ & N.M. \\
& $515,430,337,290$ & DMF \\
(7) & $510,468,348,300$ & N.M. \\
& $495,405,325,288$ & DMF \\
(8) & $540,498,355,280$ & N.M. \\
& $510,433,350,268$ & DMF \\
(9) & $520,480,335,290$ & N.M. \\
& $505,465,328,265$ & DMF \\
(10) & $525,485,350,275$ & N.M. \\
& $508,465,342,270$ & DMF \\
(11) & $538,490,350,270$ & N.M. \\
& $507,465,338,260$ & DMF \\
(12) & $515,495,365$ & N.M. \\
& $490,465,352$ & DMF \\
\hline & &
\end{tabular}

(i.e. within the aromatic ring and $\mathrm{C}=\mathrm{N}$ group). ${ }^{37}$ The complexes (2). (6) and (10) show bands in nujol mull at 525540 and $438-490 \mathrm{~nm}$ ranges. however. in DMF, it appears at $508-515$ and $430-475 \mathrm{~nm}$ ranges. attributed to ${ }^{l} \mathrm{~A}_{\mathrm{gg}} \rightarrow{ }^{-} \mathrm{E}_{\mathrm{g}}$

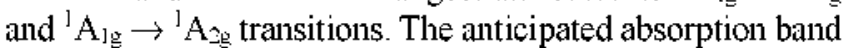
due to the ${ }^{l} \mathrm{~A}_{1 \mathrm{~g}} \rightarrow{ }^{3} \mathrm{E}_{\mathrm{g}}$ transition is probably masked by the intense charge transfer absorption at $($ N.M $=350 \mathrm{~nm}$ and DMF 330,342 and $337 \mathrm{~nm}$ respectively). ${ }^{18}$ The complexes (3). (7) and (9) exhibit bands around $535 \mathrm{~nm}$. characteristic of the square planar environment and probably arising from the ${ }^{2} \mathrm{~A}_{\mathrm{lg}}$ transition with configuration $\mathrm{e}^{+} \mathrm{gb}_{2}=\mathrm{a}_{1 \mathrm{~g}}{ }^{19}$ Complex (12) in mujol mull shows peaks at 365,495 and $515 \mathrm{~nm}$. however. in DMF. it appears at 352, 465 and $490 \mathrm{~nm}$. The first one is within the ligand and the other peaks are assigned to ${ }^{4} \mathrm{~T}_{\mathrm{lg}} \rightarrow{ }^{4} \mathrm{~T}_{\mathrm{lg}}(\mathrm{P})$ and ${ }^{4} \mathrm{~T}_{\mathrm{lg}} \rightarrow{ }^{4} \mathrm{~A}_{\mathrm{z} \mathrm{g}}$ transitions respectively. indicating an distorted octahedral structure ${ }^{2: 2}$ The electronic spectra of the complexes (4). (8) and (11) show bands in nujol mull at 538-546 and 490-505 nm ranges and in DMF it appear at 507-510 and $433-490 \mathrm{~nm}$ ranges. assigned to ${ }^{2} \mathrm{~B}_{1 \mathrm{~g}}$ $\rightarrow{ }^{-} \mathrm{B}_{\mathrm{gg}}$ and ${ }^{2} \mathrm{~B}_{1 \mathrm{~g}} \rightarrow{ }^{-} \mathrm{E}_{\mathrm{g}}$ transitions. indicating. square planar configuration. ${ }^{8 \%}$

Electron spin resonance. The ESR spectra of solid complexes (4), (8) and (11) at room temperature are characteristic of a monomer. $d^{\circ}$. configuration and having an axial type of $\mathrm{d}_{2} \cdot \mathrm{y}^{2}$ ground state. ${ }^{13.22}$ The g-values suggest a square planar geometry. ${ }^{823}$ The ESR parameters are presented in Table 4 . The g-values are related by the expression. ${ }^{24} \mathrm{G}$ $=\left(\mathrm{g}_{\|}-2\right) /\left(\mathrm{g}_{\perp}-2\right)$. If $\mathrm{G}>4.0$. Then. local tetragonal axes are aligned parallel or only slightly misaligned. if $\mathrm{G}<4.0$. significant exchange coupling is present. The complexes show $G$ values $<4.0$. (Table 4 ). indicating the presence of spin exchange interactions between the copper(II) ions. Also. the $\mathrm{g}_{\|} / \mathrm{A}_{\|}$value considered as a diagnostic of stereochemistry 25 the range reported for square planar complexes. are 105 to $135 \mathrm{~cm}^{-1}$ and for tetragonal distorted complexes 150 to $250 \mathrm{~cm}^{-1}$. The $\mathrm{g}_{\mid} / \mathrm{A}_{\mid}$values lie just within the range expected for the complexes.

The g-values of the copper(II) complexes with a ${ }^{2} \mathrm{~B}_{1 \mathrm{~g}}$ ground state $\left(g_{\mid}>g_{\perp}\right)$ may be expressed ${ }^{26.27}$ by

$$
\begin{aligned}
& \mathrm{g}_{1}=2.002-\left(8 \mathrm{~K}_{\mid}^{2} \lambda / \Delta \mathrm{E}_{\mathrm{xy}}\right) \\
& \mathrm{g}_{\perp}=2.002-\left(2 \mathrm{~K}_{\perp}^{2} \lambda / \Delta \mathrm{E}_{\mathrm{X} 2}\right)
\end{aligned}
$$

where $K_{1}$ and $K_{\perp}$ are the parallel and perpendicular components respectively of the orbital reduction factor $(\mathrm{K})$. $\lambda^{\circ}$ is the spin-orbit coupling constant for the free copper. $\Delta \mathrm{E}_{\mathrm{xy}}$ and $\Delta \mathrm{E}_{\mathrm{xz}}$ are the electron transition energies of ${ }^{2} \mathrm{~B}_{2 \mathrm{~g}}$ ${ }^{2} \mathrm{~B}_{\mathrm{lg}}$ and ${ }^{2} \mathrm{E}_{\mathrm{g}} \longleftarrow{ }^{2} \mathrm{~B}_{\mathrm{lg}}$. From the above relations. the orbital reduction factors $\left(\mathrm{K}, \mathrm{K}_{\perp}, \mathrm{K}\right)$. which are a measure of covalency. ${ }^{27}$ can be calculated. For an ionic environment. $\mathrm{K}$ $=1$ and for a covalent environment $\mathrm{K}<1$, the lower value of $\mathrm{K}$. the greater is the covalent.

$$
\begin{aligned}
& \mathrm{K}_{\perp}^{2}=\left(\mathrm{g}_{\perp}-2.002\right) \Delta \mathrm{E}_{\mathrm{Xz}} / 2 \lambda^{\circ} \\
& \mathrm{K}_{l}^{2}=\left(\mathrm{g}_{\mathrm{l}}-2.002\right) \Delta \mathrm{E}_{\mathrm{Xy}} / 8 \lambda^{\circ} \\
& \mathrm{K}^{2}=\left(\mathrm{K}^{2}+2 \mathrm{~K}_{\perp}^{2}\right) / 3
\end{aligned}
$$

$\mathrm{K}$ (Table 4) for the copper(II) complexes are indicative of their covalent nature ${ }^{28.29}$ Kivelson and Neiman ${ }^{30}$ noted that. for an ionic environment $\mathrm{g}_{\mid} \geq 2.3$ and for a covalent

\begin{tabular}{|c|c|c|c|c|c|c|c|c|c|c|c|c|c|c|c|c|}
\hline $\begin{array}{l}\text { Complex } \\
\text { No. }\end{array}$ & gl & $g_{\perp}$ & ${ }^{\sigma} \mathrm{g}_{\mathrm{j} \otimes}$ & $\begin{array}{l}\mathrm{A}_{1} \\
(\mathrm{G})\end{array}$ & $\begin{array}{l}A_{-} \\
(G)\end{array}$ & $\begin{array}{l}{ }^{b} \mathrm{~A}_{\text {ss }} \\
(\mathrm{G})\end{array}$ & $\mathrm{G}$ & $\begin{array}{l}\mathrm{g}^{\mathrm{g}} / \mathrm{A}_{\mid} \\
(\mathrm{cm})\end{array}$ & $\begin{array}{c}\Delta \mathrm{E}_{\mathrm{xy}} \\
\left(\mathrm{cml}^{-1}\right)\end{array}$ & $\begin{array}{c}\Delta \mathrm{E}_{\mathrm{kz}} \\
\left(\mathrm{cm}^{-1}\right)\end{array}$ & $\mathrm{K}_{\perp}{ }^{2}$ & $K^{2}$ & $\mathrm{~K}$ & $\alpha_{\text {(Cu }}^{2}$ & $\beta_{1}^{3}$ & $\beta^{2}$ \\
\hline (4) & 2.27 & 2.07 & 2.14 & 170 & 28 & 75.3 & 3.8 & 126 & 18315 & 19802 & 0.81 & 0.74 & 0.89 & 0.80 & 0.97 & 1.1 \\
\hline (8) & 2.25 & 2.08 & 2.13 & 165 & 25 & 71.7 & 3.1 & 132.3 & 18518 & 20080 & 0.94 & 0.69 & 0.92 & 0.75 & 0.97 & 1.3 \\
\hline (11) & 2.26 & 2.07 & 2.13 & 200 & 20 & 80 & 3.7 & 107.1 & 18587 & 20208 & 0.83 & 0.72 & 0.89 & 0.91 & 0.79 & 0.91 \\
\hline (12) & 2.12 & 2.23 & 2.19 & 42 & 85 & 70.7 & - & - & - & - & - & - & - & - & - & - \\
\hline
\end{tabular}
environment. $\mathrm{g}_{\mid}<2.3$. Theoretical work by Smith ${ }^{3]}$ seems to confirm this view. The g $\mathrm{g}_{\|}$-values reported here show considerable covalent bonding character. ${ }^{32}$ Also the in-plane

Table 4. ESR parameters of the metal complexes

${ }^{\prime \prime} \mathrm{g}_{\mathrm{iso}}=\left(\mathrm{g}_{\mid}+2 \mathrm{~g}_{-}\right) 3,{ }^{\mathrm{t}} \mathrm{A}_{\mathrm{isu}}=\left(\mathrm{A}_{\mid}-2 \mathrm{~A}_{\perp}\right) 3,{ }^{\mathrm{c} G}=\frac{\left(\mathrm{g}_{\mid}-2\right)}{\left(\mathrm{g}_{-}-2\right)}$ 
Table 5. DTA peaks and their assignunents for the metal complexes

\begin{tabular}{|c|c|c|c|}
\hline \multirow{2}{*}{$\begin{array}{c}\text { Complex } \\
\text { No. }\end{array}$} & \multicolumn{2}{|c|}{ DTA peaks $\left({ }^{\circ} \mathrm{C}\right)$} & \multirow{2}{*}{ Assigmments } \\
\hline & Endo & Exo & \\
\hline \multirow[t]{3}{*}{ (2) } & 80 & - & Dehydration process \\
\hline & - & 195 & M.P. of the complex \\
\hline & - & 350 & Decomposition of the complex \\
\hline \multirow[t]{3}{*}{ (3) } & 80 & - & Dehydration process \\
\hline & - & 200 & M.P. of the complex \\
\hline & - & 320 & Decomposition of the complex \\
\hline \multirow[t]{3}{*}{$(4)$} & 80 & - & Dehydration process \\
\hline & - & 195 & M.P. of the complex \\
\hline & - & 360 & Decomposition of the complex \\
\hline \multirow[t]{3}{*}{ (6) } & 85 & - & Dehydration process \\
\hline & - & 200 & M.P. of the complex \\
\hline & - & 370 & Decomposition of the complex \\
\hline \multirow[t]{3}{*}{ (7) } & 90 & - & Dehydration process \\
\hline & - & 205 & M.P. of the complex \\
\hline & - & 400 & Decomposition of the complex \\
\hline \multirow[t]{3}{*}{ (8) } & 85 & - & Dehydration process \\
\hline & - & 198 & M.P. of the complex \\
\hline & - & 385 & Decomposition of the complex \\
\hline \multirow[t]{4}{*}{ (9) } & 87 & & Delyydration process \\
\hline & 200 & & Loss of chloride atom \\
\hline & & 212 & M.P. of the complex \\
\hline & & 425 & Decomposition of the complex \\
\hline \multirow[t]{4}{*}{ (10) } & 85 & & Dehydration process \\
\hline & 193 & & Loss of chloride atom \\
\hline & & 208 & M.P. of the complex \\
\hline & & 430 & Decomposition of the complex \\
\hline \multirow[t]{4}{*}{ (11) } & 90 & & Dehydration process \\
\hline & 202 & & Loss of chloride atom \\
\hline & & 210 & M.P. of the complex \\
\hline & & 420 & Decomposition of the complex \\
\hline \multirow[t]{4}{*}{ (12) } & 85 & & Dehydration process \\
\hline & 185 & & Loss of chloride atom \\
\hline & & 192 & M.P. of the complex \\
\hline & & 395 & Decomposition of the complex \\
\hline
\end{tabular}

$\sigma$-covalency parameter $\hat{\alpha}(\mathrm{Cu})$ was calculated by

$\alpha^{2}(\mathrm{C} \mathrm{u})=(\mathrm{A} / 0.036)+\left(\mathrm{g}_{\mid}-2.002\right)+3 / 7(\mathrm{~g}-2.002)+0.04$

The calculated values (Table 4 ) suggest covalent bonding nature ${ }^{33}$

The in-plane and out-of-plane $\pi$-bonding coefficients $\left(\beta_{3}^{2}\right.$ and $\beta^{2}$. respectively are dependent upon the values of $\Delta \mathrm{E}_{\mathrm{xy}}$ and $\Delta \mathrm{E}_{\mathrm{x} 2}$ in the following equations $\mathrm{s}^{3 \hat{3}}$

$$
\begin{aligned}
& \hat{\alpha} \beta^{2}=\left(\mathrm{g}_{\perp}-2.002\right) \Delta \mathrm{E}_{\mathrm{Nz}} / 2 \lambda^{\circ} \\
& \hat{\alpha} \beta^{2}=\left(\mathrm{g}_{1}-2.002\right) \Delta \mathrm{E}_{\mathrm{y}} / 8 \lambda^{\circ}
\end{aligned}
$$

In this work, the complexes show $\beta_{1}^{\hat{2}}$ values 0.97 and 0.79 indicating a moderate degree of covalency in the in-plane $\pi$ bonding. while $\beta^{2}$ are $1.1,1.3$ and 0.91 indicating ionic and covalent character of the out-of-plane $\pi$-bonding. ${ }^{3+}$ The complex (12) was studied in $\mathrm{CD}_{3} \mathrm{OD}+\mathrm{D}_{2} \mathrm{O}(10 \%)$ at $77 \mathrm{~K}$. The spectrum is a characteristic of a low spin, $\mathrm{d}^{7}$ configuration. Eight lines were observed from the interaction of the unpaired electron spin with ${ }^{59} \mathrm{Co}(\mathrm{I}=7 / 2.100 \%$ abundant). The line widths are anisotropic. The ESR parameters (Table 4 ) show octahedral geometry and the $\mathrm{g}_{\perp}>$ $\mathrm{g}>2.0023$, indicating that the unpaired electron presents in the $\mathrm{d}_{22}$ orbital with a slight distortion of the symmetry around the z-axis. 35.36

DTA analysis. The DTA data show that all the complexes are thermally stable up to $80^{\circ} \mathrm{C}$ when dehydration begins. This fact is characterized by endothermic peak within $80-90$ ${ }^{\circ} \mathrm{C}$ range. corresponding to the loss of hydrated water molecules. . $^{3.37 .38}$ Endothermic peak was observed in the 165-212 ${ }^{\circ} \mathrm{C}$ range. corresponding to the melting ${ }^{9.39-42}$ However. complexes (9-12) show exothermic peak in the 230 $250^{\circ} \mathrm{C}$ range, due to the loss of $\mathrm{HCl}^{43}$ The product is stable up to $550^{\circ} \mathrm{C}$ when the organic constituents of the complexes start decomposing. finally leaving the decomposition products $\left(550-600{ }^{\circ} \mathrm{C}\right)^{9.17 .43-46}$ The DTA data for the complexes are shown in Table 1.

Effect of $\gamma$ radiation on DNA molecules in the presence of complex (12). Complex (12) has a large positive charge due to the central cobalt ion and the eight nitrogen atons. this property makes the complex highly reactive to DNA molecules. The suitability for electron-capture in DNAcobalt(III) complex (12) may be inferred from the results of $y$-radiation on the cobalt complex. This was observed by the reduction of $\mathrm{Co}$ (III) to $\mathrm{Co}$ (II) species. The efficiency of this reaction my be explotied in reducing the amount of electron adducts formed in DNA during irradiation with low radiation products. With $\gamma$ radiation. DNA molecules can be protected in the presence of Co(III) complex (12) and this could be of help to reduced of aberration in cells.

Acknowledgement. We are grateful to the Chemistry Department. Leicester University, England. for ESR measurements.

\section{References}

1. Wade. P. W: Hancock. R. D. J. Chem. Soc. Lathon Trans. 1990. 1323.

2. Melson, G. A. In Coondination Chmistry of Hacrocychic Complexes: Melson, G. A., Ed.; Plenum: New: York. 1979.

3. Kimura. E. Pwe Appl Chem. 1986. 58 . 1461.

4. Abdul Samath. S.: Raman. M.: Raman. N.: Teyasubramanian. K. T.: Ramalingam. K. Transition Het. Chent 1992. 17. 13.

5. Sargeson, A. M. Coord. Chem. Rev 1996. 151,89.

6. Cameron. J. H.: Harvey. H. B. Inorg. Chin. Acta 1992. 192. 253.

7. Kwiatkowshi, M. Kwiatkowski. E. J. Chem. Soc. Dalton Trans. 1985. 803

8. Carlin. R. L. Tramsition Met. Chem, 1965. 1.3.

9. El-Tabl. A. S: Kashar. T. I:: El-Bahnasawy. R. M: El-Monsef Ibrahim. A. Polish J. Chem. 1999. 73, 245.

10. El-Sonbati, A. Z. Transition Het. Chem. 1991. 16. 45.

11. Diab, M. A.: El-Sonbati. A. Z.: El-Sanabari, A. A.: Taha. F. I. Poll Degr and Stab. 1989. 24.51.

12. El-Tabl. A. S. Ph.D. Thesis: Menoufia University: Egypt. 1993

13. El-Tabl. A. S. Tramsition Met. Chem. 1997. 22. 259.

14. Mostafa. M. M: Ibrahim. K. M.; Moussa. M. N. H. Transition 11et. Chem. $1984,9.243$. 
15. Pulauniadavar. M:- Natarajan, C. Aust. J. Chem. 1985. 23, 737.

16. Ibrahim. K. M.: Behkeit. M. M.: Abu El-Reash. G. M. Transitiont Met. Chent 1991. 16. 189

17. Abu-El-Wafa. S. M.: Salib. K. A. R.: El-Inany. G.: Ismail. T. M. Symth. React. Whorg. Het-Org. Chem. 1990 20. 1343.

18. Grav. H.: Ball havsen, C. I. J. Am. Chem. Soc. 1963. 85. 260.

19. Figgis. B. N.: Nyholm, R. S. J. Chem. Soc. 1954. 12.

20. Eao. E.: Bi. S $\therefore$ Sun. H.: Liv, S. Sinth. React Inorg Met.-Org. Chem. 1997.27. 115

21. Geue. R. J.: Hambley. T. W.: Harrow field. J. M.: Sargeson. A. M.: Snow M. R. J. Am. Chem. Soc. 1984. 106, 5478.

22. El-Tabl. A. S. Transition Met Chem. 1997. 22, 40.

23. Bain, G. A.: West. D. X: Krejci. J.: Martinez, J. V.: Ortega, S. H.: Toscano. R. A. Potvedron 1997. 16.85.

24. Procter. I. M.: Hathaway. B. J.: Nicholls. P. N. J. Chem. Soc. (1) 1969. 1678

25. Nickless. D. E.; Power M. I.: Urbach. F. L. horg Chem. 1983. 22, 3210

26. Tomlinson. A. G.: Hathaway, B. I. J. Chem. Soc. f.A 1968, 1685. 190.

27. Ray. R. K. Inorg. Chimt Acta 1990. 174, 237.257.

28. Assour. J. M. J. Chent. Phns. 1965. 13. 2477.

29. Harrison. S. E.: Assour. J. M. J. Chem. Phys. 1964. 40.365.

30. Kivelson. D; Neiman, R. J. Chem. Phns. 1961, 35. 149.

31. Smith. D. W. J. Chem. Soc. (A) 1970,3108 .
32. El-Tabl. A. S.; Kashar, T. I. Polish J. Chem. 1998. 72. 519

33. Kuska. H. A.: Rogers. M. T. Coordination Chentistiv: Martell. A. E.. Ed.: Van1 Nostrand Reinhold Co.: N.Y.. 1971.

34. Bhadbhade. M. M.: Srinivas. D. Horg. Chem. 1993. 32.5458.

35. Ozawa. T.: Hanaki. A. Horg. Chim. Acta 1988, 153. 201.

36. Symons. M. C. R.: Wilkinson, J. G. J. Chem, Soc. Dalton 1971. 1086.

37. Geary. W. T. Coond Chem. Rev 1971. 7.81.

38. Gaber. M.: Ayad. M. M. Thernochint .Acta 1991. 176.21.

39. Abate. L.: Libertini. E.: Recca. A.: Siracusa. G. Thernochm, Acta 1983. 65,351 .

40. Cukurovali, A. Synh. React Inorg 1 1et.-Ong Chem 1997, 27. 1159.

41. Ayad. A. I.: Sallam. S. A.: Mabrouk. H. E. Thernochm. Acta 1991. 189.65

42. Ramadan. A. M.: Sawodny. W: El-Baradie. H. Y: Gaber. M. Transition 1. fet. Chem. 1997. 22.211.

43. Aly, F. A.: El-Bahnasawy. R. M.; Gaber, M.: Donia, A. M. Egypt J. Chem 1994, 37. 145

44. El-Tabl. A. S.: Abou-Selkina. M. M. Polish J. Chent 1999. 73. 1937.

45. Donia. A. M.: El-Boraey. A. H. J. Anal and Appl Pyrohsis 2002. 63.69 .

46. Brezina, F: Smekal, S. Z.: Pastorek. R. Transition Het Chem. 1996. $21,287$. 